\title{
Investigation of the Hellenistic period pottery production technology from the Seyitömer Mound (Kütahya/Turkey)
}

\author{
C. Serkaya ${ }^{1}$, A. İssi ${ }^{1}$, V. Uz ${ }^{1}$ \& A. N. Bilgen ${ }^{2}$ \\ ${ }^{I}$ Department of Materials Science and Engineering, \\ Dumlupinar University, Turkey \\ ${ }^{2}$ Department of Archaeology, Dumlupınar University, Turkey
}

\begin{abstract}
Anatolia has hosted many civilizations from ancient times to the present. There are many settlements belonging to past civilizations. One of them is the Seyitömer Mound. The Seyitömer Mound is located $25 \mathrm{~km}$ northwest of Kütahya. It is a 5,000 year-old mound. It has been enlightened that the Seyitömer Mound has been inhibited by civilizations in the Bronze Age, Achaemenid, Hellenistic and Roman periods. From the excavations performed between 2006 and 2013, over 7,000 inventorial and 20,000 finds to be examined have been delivered to the Archaeological Museum of Kütahya and 1,381 artifacts have been exhibited in one of the first private museums belonging to archaeological excavation sites in Turkey at Dumlupınar University. In this study, chemical and mineralogical/phase composition of 30 pottery body sherds unearthed in the Seyitömer Mound belonging to the Hellenistic Period (334-330 BC) have been investigated. Chemical analysis of samples was obtained by wavelength dispersive X-ray fluorescence (WDXRF) and mineralogical/phase composition was obtained by Xray diffraction (XRD). Scanning electron microscopy (SEM) and microanalysis technique (EDX) were performed for microstructural and microchemical analysis. Thermal analysis (TG-DTA) was also employed as a complementary characterization technique to estimate firing temperature of the potsherds. From the results, ceramic bodies have been produced from clay deposits rich in iron, containing illitic type minerals and carbonated minerals such as calcite and dolomite. Raw materials contain calcite-rich and magnesium minerals. Firing temperatures of the potsherds range from $600^{\circ} \mathrm{C}$ to $1100^{\circ} \mathrm{C}$.
\end{abstract}

Keywords: Seyitömer Mound, Hellenistic period, ceramic artifact, characterization, archaeometry. 


\section{Introduction}

Civilizations existed in Anatolia and their belongings became a huge cultural heritage. Every effort like evaluation, conserving or restoration to carry them to future of these artifacts is valuable. Archaeometrical studies gather different branches of science such as materials science, physics, chemistry and others. Archaeological ceramics may be investigated with different characterization techniques to enlighten production technology of the wares (Papachristodoulou et al. [1], Barone et al. [2]).

The Seyitömer Mound is located $25 \mathrm{~km}$ northwest of the centre of Kütahya province. The Mound is $150 \times 140 \mathrm{~m}$ in size and has a height of $23.5 \mathrm{~m}$. In order to receive 12 million tonnes of coal reserve under the Mound, archaeological excavations are being held in the archaeological site. The archaeological excavations were started in 1989. It has been enlightened that the Seyitömer Mound has been inhabited by civilizations in the Bronze Age, Achaemenid, Hellenistic and Roman periods (Bilgen [3]). 30 pottery sherds unearthed in the Seyitömer Mound belonging to the Hellenistic period have been investigated. Chemical analysis of samples was performed by wavelength dispersive X-ray fluorescence (WDXRF) and mineralogical/phase composition analysis was performed by X-ray diffraction (XRD) (Vinagre et al. [4], Demirel et al. [5], Kennett et al. [6]) to perform archaeometrical characterization of the artifacts. Scanning electron microscopy (SEM) and energy dispersive spectroscopy (EDS) used for identification of microstructural and microchemical properties of the samples. Thermogravimetric-differential thermal analysis (TG-DTA) was performed to observe the thermal behaviors of the samples to predict the maximum firing temperatures.
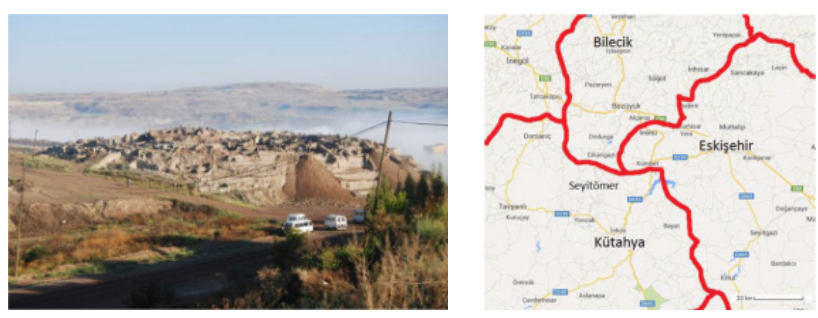

Figure 1: A photograph and a map showing the location of the Seyitömer Mound.

\section{Materials and methods}

The representative photos of the Hellenistic period samples coded as H8, H14, H15 and H20 were given in Figure 2.

Determined parts of the samples were cut by diamond cutting discs and 0.8 $1.5 \mathrm{~g}$ of samples were obtained. Samples were stored in deionized water to remove impurities for 2 days. Cleaned samples were dried at room temperature. Powder 


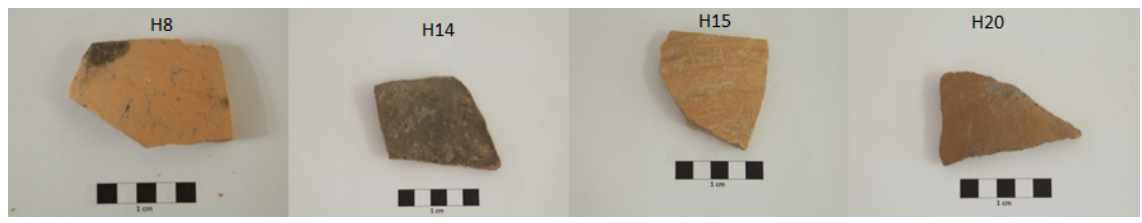

Figure 2: $\quad$ Photos of H8, H14, H15 and H20 coded samples.

of the samples was prepared in agate mortars to perform the analysis. A Rigaku Miniflex powder diffractometer with $\mathrm{Cu} \mathrm{K \alpha}$ radiation $(\lambda=1.5418 \AA)$ was used for the mineralogical analysis. XRD patterns were obtained by scanning $5^{\circ}$ to $55^{\circ}$ in $2 \theta$, with a goniometer speed of $2 \% \mathrm{~min}$, operating at $40 \mathrm{kV}$ and $30 \mathrm{~mA}$. The interpretation of mineralogical content of the data was conducted with JADE 7 software by searching and matching the powder diffraction files. A Rigaku ZSX primus wavelength dispersive X-ray fluorescence (WDXRF) instrument was used for chemical analysis of the elements. The measurements were carried out on glass tablets prepared by fluxing powdered samples with $\mathrm{Li}_{2} \mathrm{~B}_{4} \mathrm{O}_{7}$ in 1:10 weigh ratio. The calculation of the semi-quantitative results was conducted with ZSX software. The results were given as oxides. The microstructural and microchemical aspects of the representative potsherds were investigated using FEI Nova Nano 650 SEM instrument. Setaram Labsys Evo instrument was used for TG-DTA analysis. A heating rate of $10^{\circ} \mathrm{C} / \mathrm{min}$ was performed in oxidative atmosphere from room temperature to $1200^{\circ} \mathrm{C}$.

\section{Results and discussions}

\subsection{Chemical analysis result and discussion}

Instead of giving all the results of the study, chemical analysis results belonging to $\mathrm{H} 8, \mathrm{H} 14, \mathrm{H} 15$ and $\mathrm{H} 20$ which are calcium poor and rich and representing chemical analysis of ceramic groups were given in Table 1.

As seen from the results, the maximum percentage of $\mathrm{CaO}$ belongs to $\mathrm{H} 20$ coded sample, the minimum percentage belongs to $\mathrm{H} 15$ coded sample. Considering total of alkaline and alkaline-earth oxides, H20 has the maximum quantity.

\subsection{Mineralogical/phase analysis results and discussion}

Determined minerals/phases for the samples are: Quartz $\left(\mathrm{SiO}_{2}\right)$, Plagioclase, Illite $\left(\left(\mathrm{K}, \mathrm{H}_{3} \mathrm{O}\right) \mathrm{Al}_{2} \mathrm{Si}_{3} \mathrm{AlO}_{10}(\mathrm{OH})_{2}\right)$, Microcline $\left(\mathrm{KAlSi}_{3} \mathrm{O}_{8}\right)$, Calcite $\left(\mathrm{CaCO}_{3}\right)$, Muscovite $\left(\mathrm{KAl}_{2}\left(\mathrm{Si}_{3} \mathrm{Al}\right) \mathrm{O}_{10}(\mathrm{OH}, \mathrm{F})_{2}\right)$, Gehlenite $\left(\mathrm{Ca}_{2} \mathrm{Al}_{2} \mathrm{SiO}_{7}\right)$, Dolomite $\left(\mathrm{CaMg}\left(\mathrm{CO}_{3}\right)_{2}\right)$, Hematite $\left(\mathrm{Fe}_{2} \mathrm{O}_{3}\right)$, Maghemit $\left(\mathrm{Fe}_{2} \mathrm{O}_{3}\right)$, Blue Dioptase $\left(\mathrm{CuSiO}_{2}(\mathrm{OH})_{2}\right)$, Hedenbergite $\left(\mathrm{CaFe}^{+2} \mathrm{SiO}_{2} \mathrm{O}_{6}\right)$. XRD analysis results of $\mathrm{H} 8, \mathrm{H} 14, \mathrm{H} 15$ and $\mathrm{H} 20$ coded samples and raw materials of clays are given in Table 2. 
Table 1: Chemical analysis results of H8, H14, H15 and H20. The term of "n.d." indicates not detected or under the limits of detection by WDXRF technique performed.

\begin{tabular}{|c|c|c|c|c|}
\hline \multirow[b]{2}{*}{ Oxide } & \multicolumn{2}{|c|}{ Calcium Rich } & \multicolumn{2}{|c|}{ Calcium Poor } \\
\hline & H8 & H20 & H14 & H15 \\
\hline $\mathrm{Na}_{2} \mathrm{O}$ & 1.3622 & 1.8263 & 1.7577 & 3.7479 \\
\hline MgO & 4.5568 & 3.7391 & 9.2439 & 3.8566 \\
\hline $\mathrm{Al}_{2} \mathrm{O}_{3}$ & 17.7377 & 11.0083 & 14.4558 & 13.8415 \\
\hline $\mathrm{SiO}_{2}$ & 54.9392 & 48.4078 & 58.7664 & 66.2611 \\
\hline $\mathrm{P}_{2} \mathrm{O}_{5}$ & 0.293 & 0.3288 & 0.1303 & 0.1496 \\
\hline $\mathrm{SO}_{3}$ & 0.1149 & 0.173 & 0.0577 & 0.1202 \\
\hline CI & 0.0394 & 0.1273 & 0.0658 & 0.2906 \\
\hline $\mathrm{K}_{2} \mathrm{O}$ & 3.6782 & 2.4415 & 2.4104 & 2.4392 \\
\hline $\mathrm{CaO}$ & 9.9239 & 25.8409 & 1.673 & 1.0684 \\
\hline $\mathrm{TiO}_{2}$ & 0.8235 & 0.5381 & 0.6454 & 0.7514 \\
\hline $\mathrm{V}_{2} \mathrm{O}_{5}$ & n.d. & n.d. & n.d. & n.d. \\
\hline $\mathrm{Cr}_{2} \mathrm{O}_{3}$ & 0.0449 & 0.0584 & 0.1815 & 0.0742 \\
\hline MnO & 0.1099 & 0.1842 & 0.1661 & 0.1341 \\
\hline $\mathrm{Fe}_{2} \mathrm{O}_{3}$ & 6.2633 & 5.185 & 9.9196 & 7.0957 \\
\hline $\mathrm{Co}_{2} \mathrm{O}_{3}$ & n.d. & n.d. & n.d. & n.d. \\
\hline $\mathrm{NiO}$ & 0.0231 & 0.0406 & 0.1316 & 0.058 \\
\hline $\mathrm{CuO}$ & 0.0157 & n.d. & 0.015 & 0.0154 \\
\hline $\mathrm{ZnO}$ & 0.0288 & 0.0157 & 0.0235 & 0.0194 \\
\hline $\mathrm{As}_{2} \mathrm{O}_{3}$ & n.d. & n.d. & n.d. & n.d. \\
\hline $\mathbf{R} \mathbf{b}_{2} \mathbf{O}$ & n.d. & n.d. & n.d. & 0.0367 \\
\hline SrO & 0.0235 & 0.0616 & 0.0144 & 0.0124 \\
\hline $\mathrm{ZrO}_{2}$ & 0.0219 & 0.0236 & 0.0165 & 0.0277 \\
\hline $\mathrm{BaO}$ & n.d. & n.d. & 0.3253 & n.d. \\
\hline $\mathrm{SnO}_{2}$ & n.d. & n.d. & n.d. & n.d. \\
\hline $\mathrm{Nb}_{2} \mathrm{O}_{5}$ & n.d. & n.d. & n.d. & n.d. \\
\hline $\mathrm{Ag}_{2} \mathrm{O}$ & n.d. & n.d. & n.d. & n.d. \\
\hline
\end{tabular}


Table 2: $\quad$ XRD analysis results of H8, H14, H15 and H20 coded samples and raw materials of clays.

\begin{tabular}{|c|c|}
\hline Sample Code & Minerals/Phases \\
\hline H8 & $\begin{array}{c}\text { Quartz, Plagioclase, Illite, Microcline, Calcite, Gehlenite, } \\
\text { Hematite, Maghemite. }\end{array}$ \\
\hline H14 & Quartz, Plagioclase, Illite, Microcline, Blue Dioptase, Maghemite. \\
\hline H15 & Quartz, Plagioclase, Muscovite, Gehlenite, Hedenbergite. \\
\hline $\mathbf{H 2 0}$ & Quartz, Plagioclase, Muscovite, Calcite, Dolomite, Maghemite. \\
\hline SNLKKY & $\begin{array}{l}\text { Quartz, Plagioclase, Illite/Muscovite, Montmorillonite, Kaolinite, } \\
\text { Calcite, Dolomite. }\end{array}$ \\
\hline AYVALIB & $\begin{array}{l}\text { Quartz, Plagioclase, Illite/Muscovite, Talc, Kaolinite, Kaliophilite, } \\
\text { Calcite, Dolomite. }\end{array}$ \\
\hline CKOY2B & $\begin{array}{l}\text { Quartz, Plagioclase, Illite/Muscovite, Kaolinite/Montmorillonite, } \\
\text { Calcite. }\end{array}$ \\
\hline IK3A & $\begin{array}{l}\text { Quartz, Plagioclase, Illite/Muscovite, Talc, Montmorillonite, } \\
\text { Kaolinite, Calcite. }\end{array}$ \\
\hline SO1K & $\begin{array}{l}\text { Quartz, Plagioclase, Illite/Muscovite, Montmorillonite, Kaolinite, } \\
\text { Calcite, Dolomite. }\end{array}$ \\
\hline
\end{tabular}

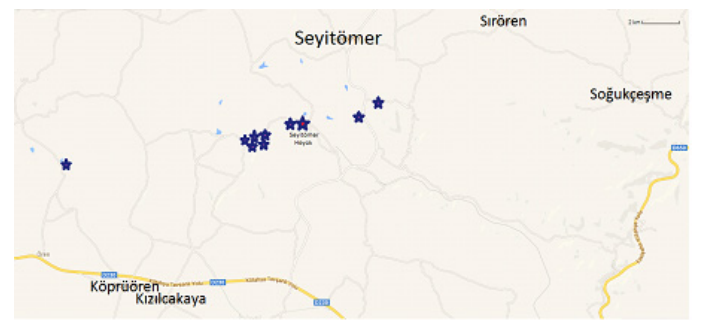

Figure 3: Shows the raw materials (clays) collected around the Seyitömer Mound.

XRD results of the raw materials (clays) collected around the Seyitömer Mound are also given in Table 2. They were coded as SNLKKY, AYVALIB, CKOY2B, IK3A and SO1K.

Quartz is a mineral with high heat of melting. For this reason, quartz mineral exists in all samples. Quartz and feldspars can persist up to $1000^{\circ} \mathrm{C}$ (İssi et al. [7]). Gehlenite begins to form at $800^{\circ} \mathrm{C}$ and disappear at $900^{\circ} \mathrm{C}$ (Veniale [8]). Illite/muscovite or mica structure breaks down in the range of $900-1000^{\circ} \mathrm{C}$ (Grimshaw [9]). Gehlenite may be formed at $850^{\circ} \mathrm{C}$ with the reaction of $\mathrm{CaO}$ and illite structure, diopside may be generated from dolomite and silica reactions at 800-900 ${ }^{\circ} \mathrm{C}$ (Cultrone et al. [10]).

H14, H15 and H20 coded samples contain illite/muscovite minerals. They could have been fired under $1000^{\circ} \mathrm{C}$. $\mathrm{H} 8$ coded sample contains gehlenite mineral. $\mathrm{H} 8$ coded sample possibly sintered around $800^{\circ} \mathrm{C}$. Calcite and dolomite 
decomposition begin under $700^{\circ} \mathrm{C}$ and is completed up to $850^{\circ} \mathrm{C}$ (López-Arce et al. [11]). Therefore, H20 coded sample could have been fired in the lowest temperature. Another suggestion from the results is related with the atmosphere of firing. Hematite indicates oxidative firing (Damjanovic et al. [12]). However, existence of maghemite phase on XRD pattern cannot be excluded but, reductive atmosphere should have been provided for firing (Legodi and de Waala [13]). H14 sample contains blue dioptase. Dioptase decomposition begins around $400^{\circ} \mathrm{C}$ and it is completed at $730^{\circ} \mathrm{C}$ (Frost and $\mathrm{Xi}$ [14]). Therefore, estimated firing temperature could not exceed these firing temperature ranges.

\subsection{SEM analysis results and discussion}

SEM images of Ca rich and poor samples are given in Figure 4.

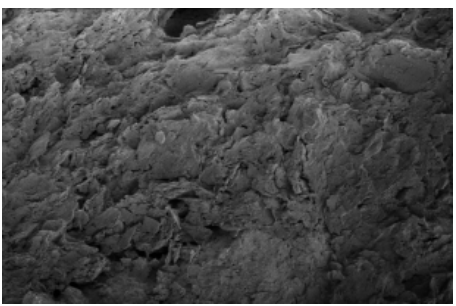

(a)

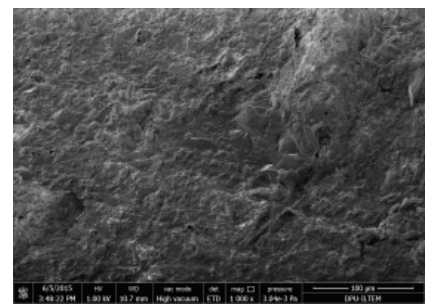

(b)

Figure 4: $\quad$ SEM images of Ca rich H20 coded sample (a) and Ca poor H15 coded sample (b).

Some changes with increasing temperature in clay based ceramics can be described as; interactions between clay matrix and grains, shape changes of grains, increase of the aggregation rate within the clay matrix with the formation of secondary porosity and formation of intergranular bridges. These changes become more evident in calcareous clays than the siliceous materials including clays (Riccardi et al. [15]). Since some of the samples contain high amounts of calcium, SEM images exhibited predominantly arrangements of calcium rich new mineral formations in the microstructure of the samples (Figure 4(a)). Quartz is one of the primary components of clay based ceramics with high melting temperature. It is considered that quartz is relatively insoluble below $1250^{\circ} \mathrm{C}$, dissolution of quartz forms silica-rich amorphous solution rims around quartz grains (Iqbal and Lee [16]). Quartz grain dissolution into vitrified clay matrix of the sample may easily be distinguished by the atomic contrast difference in BSE images. Feldspar is believed to melt around $1100^{\circ} \mathrm{C}$ in the contact zone between feldspar crystals and clay relicts and potash matrix require high temperature around $1200^{\circ} \mathrm{C}$.

\subsection{Thermogravimetric-differential thermal analysis (TG-DTA) results and discussion}

Changes occurred due to the decomposition, transformation and formation reactions during a controlled heating process may be examined from TG-DTA 
method (Drebushchak et al. [17]). Samples were heated from room temperature to $1200^{\circ} \mathrm{C}$ with a heating rate of $10^{\circ} \mathrm{C} / \mathrm{min}$ in order to expose the enthalpy changes (plotted by DTA curves with endothermic and exothermic effects) and weight loss/gain (plotted by TG curves). The endothermic effect from room temperature to $200^{\circ} \mathrm{C}$ is due to the release of hygroscopic water (Maritan et al. [18]). At higher temperatures of $200-300^{\circ} \mathrm{C}$ the endothermic effect depicts the removal of the chemically bound water, but it may not met in the present study (Paama et al. [19]). Depending on the area of the peaks observed in the range of $200-650^{\circ} \mathrm{C}$, the exothermic effect identified within these temperatures was attributed to the combustion of organic materials, not completely burnt during firing in reducing condition and transformed into carbonaceous particles, which are thought to be deliberately added into the ceramic paste to increase its plasticity or were contained in the clay utilized in the manufacture (Palanivel and Rajesh Kumar [20]). The endothermic effects observed at $700-875^{\circ} \mathrm{C}$ indicated the decarbonation reactions of mainly calcite and dolomite (Meyvel et al. [21]).

TG-DTA results of selected samples are given in Figures 5 and 6.

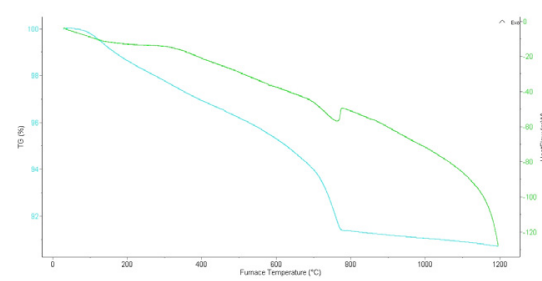

(a)

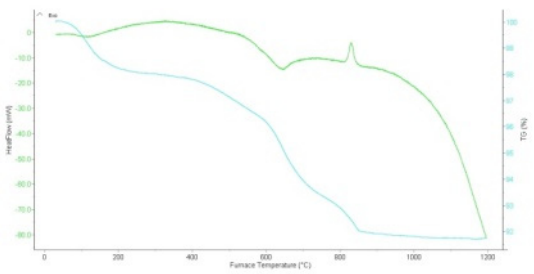

(b)

Figure 5: TG-DTA curve of the sample of H8 (a) and H14 (b).

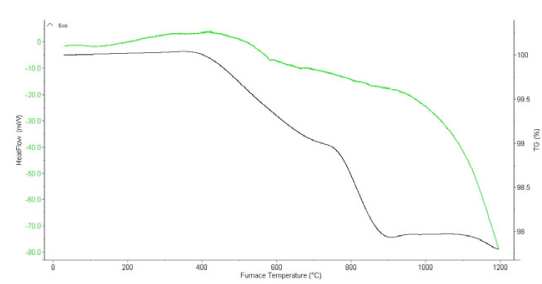

(a)

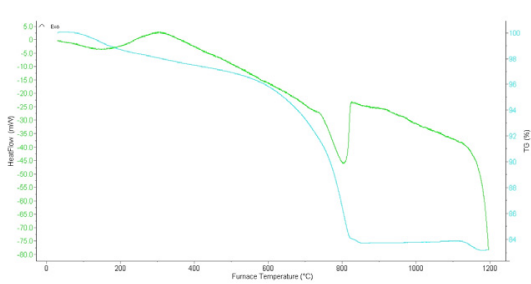

(b)

Figure 6: TG-DTA curve of the sample of H15 (a) and H20 (b).

As it can be seen from Figure 5, mass loss peak in $\mathrm{H} 8$ coded sample is $8 \%$. Mass change is methodical up to $680^{\circ} \mathrm{C}$. Considering TG analysis with XRD results weight originates from that heats are from the reactions of unbound or adsorbed water loss or burning of organic substance. According to DTA analysis endothermic reactions in $770^{\circ} \mathrm{C}$ depends on calcite decomposition for $\mathrm{H} 8$ coded sample. Mass loss peak in $\mathrm{H} 14$ coded sample is around $8 \%$ and similar with $\mathrm{H} 8$ coded sample. DTA analysis shows the endothermic reaction in $640^{\circ} \mathrm{C}$ depends 
on calcite decomposition for $\mathrm{H} 14$ coded sample. Also exothermic reaction in $840^{\circ} \mathrm{C}$ shows new crystallizations are occurred. Mass loss peak in $\mathrm{H} 15$ coded sample is around $2.5 \%$. DTA analysis shows the endothermic reaction in $575^{\circ} \mathrm{C}$ depends on crystal water decomposition for $\mathrm{H} 15$ coded sample. Mass loss peak is around $15 \%$ in $\mathrm{H} 20$ coded sample and exothermic reaction in $300^{\circ} \mathrm{C}$ occurred organic based component burnt. Endothermic reaction in $800^{\circ} \mathrm{C}$ depends on calcite decomposition for $\mathrm{H} 20$ coded sample.

\section{Conclusions}

From WDXRF, XRD, SEM and TG-DTA analysis results obtained, the Hellenistic period ceramics unearthed in the Seyitömer Mound have been produced from clay deposits containing illitic type minerals with rich in iron and calcium rich and poor accessory minerals. To compare with regional geological formations and raw material sources, it may be suggested that local raw material source is enough to produce such kind of ceramic wares during the Hellenistic period. According to phases/minerals in Hellenistic period samples firing temperatures are between $600^{\circ} \mathrm{C}$ and $1100^{\circ} \mathrm{C}$.

\section{Acknowledgement}

This study is a part of ongoing project titled "Archaeometrical Characterization of Ceramic Findings Belonging to Achaemenid, Hellenistic and Roman Periods from Seyitömer Mound (Kütahya)" with the project number of 113K096. The Scientific and Technological Research Council of Turkey (TÜBİTAK) is acknowledged.

\section{References}

[1] Papachristodoulou C., Oikonomou A., Ioaniddes K. \& Gravani K., A Study of Ancient Pottery by Means of X-Ray Fluorescence Spectroscopy, Multivariate Statistics and Mineralogical Analysis. Analytica Chimica Acta., 573, pp. 347-353, 2006.

[2] Barone G., Crupi V., Galli S., Majolino D., Migliardo P. \& Venuti V., Spectroscopic İnvestigation of Greek Ceramic Artefacts. Journal of Molecular Structure, 651, pp. 449-458, 2003.

[3] Bilgen, A.N., Seyitömer Höyük Kazısı Ön Raporu. P.1 Kütahya, 2011 (in Turkish).

[4] Vinagre U. M., Latini R. M., Bellido A. V. B., Buarque A. \& Borges A. M., Ancient Ceramics Analysis by Neutron Activation in Association with Multivare Methods, Brazilian Journal of Physics, 35, pp. 779-781, 2005.

[5] Demirel M., Sevin F. B., Say R. \& Yazan Y., Propranolol HCl Imprinted Polymeric Microspheres: Development, Characterization and Dissolution. FABAD J. Pharm. Sci., 32, pp. 147-157, Ankara, 2007. 
[6] Kennett D. J., Sakai S., Neff H., Gossett R. \& Larson D. O., Compositional Characterisation of Prehistoric Ceramics: A New Approach. Journal of Archaeological Science, 29, pp. 443-455, 2002.

[7] Issi, A., Kara A. \& Alp, A.O., An Investigation of Hellenistic Period Pottery Production Technology from Harabezikan/Turkey. Ceramics International, 37, pp. 2575-2582, Eskişehir, 2011.

[8] Veniale F., Modern techniques of analysis applied to ancient ceramics. In: Advanced workshop on analytical methodologies for the investigation of damaged Stones, Pavia, (Italy), 1990.

[9] Grimshaw R.W., The Chemistry and Physics of Clays. Techbooks, p. 727, India, 1971.

[10] Cultrone G., Navarro C. R., Sebastian E., Cazalla O. \& Torre M. J., Carbonate and Silicate Phase Reactions during Ceramic Firing. Eur. J. Mineral, 13, pp. 621-634, Stuttgart (Germany), 2001.

[11] López-Arce P., Garcia-Guinea J., Gracia M. \& Obis J., Bricks in historical buildings of Toledo City: characterisation and restoration. Mater. Charact., 50, pp. 59-68, 2003.

[12] Damjanovic L., Antunovic I. H., Mioc U. B, Bikic V., Milanovic D. \& Evans I. R., Archaeometric study of medieval pottery excavated at Stari (Old) Ras Serbia. J. Archaeol. Sci., 38, pp. 818-828, 2011.

[13] Legodi, M. A. \& de Waala M. A. The preparation of magnetite, goethite, hematite and maghemite of pigment quality from mill scale iron waste. Department of Chemistry, University of Pretoria, v.74, i.1, pp. 161-168, Pretoria (South Africa), 2007.

[14] Frost L. R. \& Xi Y. Thermogravimetric analysis of the copper silicate mineral dioptase. Journal of Thermal Analysis \& Calorimetry. Vol. 112, Issue 2, pp. 615-619, 2013.

[15] Riccardi M. P., Messiga B. \& Duminuco P., An approach to the dynamics of clay firing. Appl. Clay Sci., 15, pp. 393-409, 1999.

[16] Iqbal Y. \& Lee W. E., Microstructural evolution in triaxial porcelain. J. Am. Ceram. Soc., 83, pp. 3121-3127, 2000.

[17] Drebushchak V. A., Mylnikova L. N., Drebushchak T. N. \& Boldyrev V. V., The investigations of ancient pottery. J. Therm. Anal. Calorim., 82, pp. 617-626, 2005.

[18] Maritan L., Nodari L., Mazzoli C., Milano A. \& Russo U., Influence of firing conditions on ceramic products: experimental study on clay rich in organic matter. Appl. Clay Sci., pp. 311-315, 2006.

[19] Paama L., Pitkanen I. \& Peramaki P., Analysis of archaeological samples and local clays using ICP-AES, TGDTG and FTIR techniques. Talanta, 51, pp. 349-357, 2000.

[20] Palanivel R. \& Rajesh Kumar U., Thermal and spectroscopic analysis of ancient potteries. Rom. J. Phys., 56, pp. 195-208, 2011.

[21] Meyvel S., Sathya P. \& Velraj G., Thermal characterization of archaeological potsherds recently excavated in Nedunkur, Tamilnadu, India. Cerâmica, 58, pp. 338-341, 2012. 